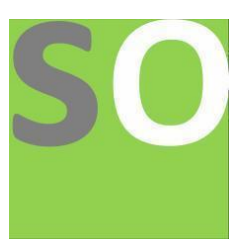

Article title: Policy learning from influenza and the preparedness of the public health sector: 2006/2007 influenza season in Latvia

Authors: leva_Daniela Beinarovica[1]

Affiliations: Department of political science, University of Latvia, Lauvas iela 4, Riga Latvia, LV-1019.[1]

Orcid ids: 0000-0002-7119-1882[1]

Contact e-mail: i.beijnarowitz@gmail.com

License information: This work has been published open access under Creative Commons Attribution License http://creativecommons.org/licenses/by/4.0/, which permits unrestricted use, distribution, and reproduction in any medium, provided the original work is properly cited. Conditions, terms of use and publishing policy can be found at https://www.scienceopen.com/.

Preprint statement: This article is a preprint and has not been peer-reviewed, under consideration and submitted to ScienceOpen Preprints for open peer review.

DOI: 10.14293/S2199-1006.1.SOR-.PPXG57D.v2

Preprint first posted online: 22 June 2021

Keywords: policy learning, policy making, crisis management, emergency management, influenza 


\title{
Policy learning from influenza and the preparedness of the public health sector: 2006/2007 influenza season in Latvia
}

\begin{abstract}
Due to globalization and continuous mutation and development of various pathogens, infectious diseases have transcended the public health sector and become issues of Global Public Health Security. Influenza - an infectious disease that is both a cyclical, yearly occurrence and the cause of several deadly global pandemics - regularly challenges the public health sector thus providing opportunities for policy learning and evidence bases policy change. By applying the Algorithm for continuous analysis of policy learning and policy change, this publication investigates whether and how policy learning and policy change took place in Latvia after the 2006/2007 influenza season, when a record number of infection cases was registered. Although the conclusions of this publication cannot be generalized, it provides valuable insights for future research, especially for the analysis of the management of the Covid-19 pandemic in Latvia.
\end{abstract}

Key words: policy learning, evidence based policy making, emergency management.

\section{Introduction}

The Covid-19 global pandemic exposed the many weaknesses and vulnerabilities of public health sectors as well as many social inequalities all over the world. In this respect Latvia was no exception: hospitals were understaffed and stretched to their limits; the medical professionals - overworked and underpaid; there were no reserves of PPE; infection rates in state social care facilities housing some of the most vulnerable societal groups soared. The media regularly published warnings expressed by representatives of the medical community about the healthcare system being on the brink of collapse. Although the onset of the Covid-19 pandemic was quite rapid, the problems and vulnerabilities it exposed were constructed over the three decades since Latvia had regained its independence after the collapse of the Soviet Union.

Covid-19 pandemic just like the countless emergencies before and since create opportunities for policy learning and policy change. Whether these opportunities are embraced by policy makers and lessons are formalized into policy documents is a question worth exploring both from the perspective of emergency management and evidence based policy making. The processes of policy learning and policy change can be explored through each of several theoretical frameworks: Mays's theory of learning from policy failure (May, 1992); Etheredge's theory of government learning (Etheredge, 1985); Heclo's theory of political learning (Heclo, 1974); Rose's theory of lesson-drawing (Rose, 1991); Hall's theory of social 
learning (Hall, 1993); Sabatier's Advocacy Coalition framework and theory of policy-oriented learning (Sabatier and Jenkins-Smith, 1993), or by applying Birkland's Model of Event-Related Policy Change (Birkland, 2006) which combines elements of all of the above.

To gain a better understanding of successes or failures of managing any emergency it important to understand both if policy learning and policy change took place after a specific incident or similar incidents in the past and why it did or did not happen. Only then evidence based solutions can be formulated and successfully applied. Birkland's Model of Event-Related Policy Change offers a solid framework for evaluating policy learning and change, however it is aimed at evaluating prima facie policy learning and policy change. Even though emergencies of large scale and magnitude - "catastrophes" (Faulkner, 2001; Birkland, 2006) or "extreme events" (Kapucu and van Wart, 2006) are rare, various emergencies (crises, disasters, accidents) are part of our daily lives and cycles of nature, and might expose various vulnerabilities that policymakers might not be aware of. Modern technologies allow us never before seen access to information thus offering a continuous stream of data for vulnerability and risk analysis and evidence based approach to policy making.

This article aims to analyse the capability of Latvia's public administration institutions to perform policy learning and policy change after emergencies in the public health sector and understanding the specific context which lead to successes or failures regarding the formalization and implementation various policies thus offering valuable lessons to policy makers both locally and internationally. This article makes an important contribution to understand policy learning and policy change in the context of emergency management in the public health sector in Latvia, based on a case study of the 2006/2007 influenza season. In the context of current global events this article is also expected to contribute to future analysis of the management of the Covid-19 pandemic by introducing a new analytical tool.

The rest of the article is structured in the following way: first I outline the theoretical framework of the study, research questions and methodology. Next I provide the reasoning 
behind this case study and a brief overview of the 2006/2007 influenza season in Latvia. Next I will discuss various agendas that are crucial in fostering policy learning and policy change as well as (potential) critical failures of the case. Finally, I apply the Algorithm for continuous analysis of policy learning and policy change to the case and discuss the results of policy learning and policy change, contributing factors and future directions for research.

\section{Policy learning - a never ending cycle}

Birkland created the Model of Event-related policy learning to 1) explain and illustrate the process of policy learning and change after focusing event in a cause-to-effect fashion, drawing from various theories on the actions of stakeholders involved in the policymaking process, and 2) to "suggest the data needed to understand a given event". (Birkland, 2006, p. 17). Birkland's model is based on the definition of (policy) "learning" as given by Busenberg: "process in which individuals apply new information and ideas to policy decisions". (Busenberg, 2001, p. 173) This definition will also be applied in the context of this publication, because it points to a crucial factor that differentiates policy learning from any other type of learning - application of information and ideas to policy decisions. Consequently, "policy change refers to incremental shifts in existing structures, or new and innovative policies (Bennett and Howlett 1992)". (Cerna, 2013, p. 4) Although in every theory (summarized in Table 1) used by Birkland individuals of various affiliations are the ones who learn, unless this new knowledge is formalized in a policy document there can be no discussion of policy learning (and subsequent policy change). This must be emphasized in order to minimize the risk of research becoming individual-focused and only evaluating the increases of individual knowledge, competencies or the perception thereof, because these do not automatically lead to improved or changed policies. An idea for policy change must be wetted and formalized in a policy document via an established and agreed upon policymaking process to make it legally binding to a wider public be it an organization or institution, municipality, state or country. To ensure this, said idea needs support - an institution, organization or advocacy coalition that has 
the necessary resources and knowhow - which then can be used as a tool for successfully transforming individual knowledge into a legally binding norm.

Birkland's Model of Event-related policy learning offers six prepositions that suggest the necessary data for analysis: 1) Only few events will gain the most attention; 2) Focusing events create group mobilization; 3) Events create opportunities for discussing (existing) ideas; 4) Only few ideas issues are completely new; 5) meaningful discussion of ideas and the resulting policy learning and change after focusing events is not guaranteed - policy change can occur without learning; and 6) (policy) learning decays over time. (Birkland, 2006, pp. 1820) Thus the following primary data sources are: media publications/news; data bases of policy documents and laws, broadcasts or meeting minutes or relevant working groups, interest groups and institutions. This leads to data collection being partially structured - one source leads to another, e.g., a news publication mentions an obscure interest group or a project of a policy document that would be interesting only to individuals with specialized knowledge.

By combining Birkland's Model of Event-related policy learning and its six prepositions with elements from the Taxonomy of organizational learning from rare events (Carley and Harrald, 2001, p. 120) and Deming's cycle (Project Management Institute, 2008) and with practices of business process management, an algorithm (e.g. a standard ${ }^{1}$ against which the information acquired is to be compared) can be constructed that potentially allows to make judgements about more than just the fact prima facie policy learning (Figure 1). The conclusions, just like in the case of Birkland's model, are context specific for each case study and cannot be generalized, however the algorithm helps to decrease the subjective nature of said judgements by demanding an objective assessment of indicators against the identified critical failures.

\footnotetext{
${ }^{1}$ Evidence for assessing policy learning is derived by collecting data, applying context to said data thus converting the data into information and comparing the information to a standard or reference value. (Dammann, 2019) Thus said standards can be, e.g., ISO, STANAG, policy documents, value statements, election programs or theoretical models.
} 


\begin{tabular}{|c|c|c|c|c|c|}
\hline Name of the theory & The essence of learning & Who learns? & Learns what? & $\begin{array}{c}\text { What does the learning result } \\
\text { in? }\end{array}$ & Evidence \\
\hline $\begin{array}{ll}\text { Government } & \text { learning } \\
\text { (Etheredge) } & \end{array}$ & 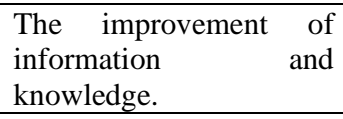 & $\begin{array}{l}\text { Executives } \\
\text { Intelligence services }\end{array}$ & $\begin{array}{l}\text { The analysis of the components } \\
\text { of a situation and events }\end{array}$ & $\begin{array}{l}\text { Changes in policies, that reflect } \\
\text { the increase of knowledge and } \\
\text { effectiveness. }\end{array}$ & $\begin{array}{l}\text { (increase in knowledge and } \\
\text { information about the specific } \\
\text { issue and its context) }\end{array}$ \\
\hline Political learning (Heclo) & Adjusting policy. & $\begin{array}{l}\text { Political institutions } \\
\text { Interest groups } \\
\text { Administrative institutions } \\
\text { Experts }\end{array}$ & To adapt to new circumstances & $\begin{array}{l}\text { Changes in policies; } \\
\text { Paradigm change. }\end{array}$ & $\begin{array}{l}\text { Changes in policy - changed } \\
\text { instruments or aims }\end{array}$ \\
\hline Lesson-drawing (Rose) & $\begin{array}{l}\text { Deliberate definition of } \\
\text { political choices via } \\
\text { analysis of the actions of } \\
\text { other institutions. }\end{array}$ & $\begin{array}{l}\text { Adjusting of policy networks } \\
\text { (officials, } \\
\text { politicians, interest groups, } \\
\text { academic environment and } \\
\text { other stakeholders) }\end{array}$ & $\begin{array}{l}\text { Policy instruments in other } \\
\text { public administration } \\
\text { organizations - their } \\
\text { advantages, disadvantages and } \\
\text { whether they are applicable to in } \\
\text { a particular situation. }\end{array}$ & Change in policies/ programs. & $\begin{array}{l}\text { Changes in policy - changed } \\
\text { policy instruments }\end{array}$ \\
\hline Social learning (Hall) & $\begin{array}{l}\text { Deliberate attempt to } \\
\text { adjust policy goals or } \\
\text { methods, by reacting to } \\
\text { past experience or new } \\
\text { information. }\end{array}$ & $\begin{array}{l}\text { Policy communities, (officials, } \\
\text { bureaucrats, politicians, } \\
\text { academic environment). }\end{array}$ & $\begin{array}{l}\text { Understanding ideas - views on } \\
\text { social reality and the causal } \\
\text { relations in it. }\end{array}$ & Change of policy paradigm. & $\begin{array}{l}\text { 1)Adjustments of existing } \\
\text { policy instruments based on } \\
\text { experience/past events; } \\
\text { 2) Change of policy } \\
\text { instruments; } \\
\text { 3) Change in policy goals. }\end{array}$ \\
\hline $\begin{array}{l}\text { Learning from policy failure } \\
-\quad \text { instrumental learning } \\
\text { (May) }\end{array}$ & $\begin{array}{l}\text { Policy elites in a specific } \\
\text { policy domain learn from } \\
\text { direct or indirect } \\
\text { experience with a specific } \\
\text { policy. }\end{array}$ & $\begin{array}{l}\text { Policy elites (officials, } \\
\text { bureaucrats, politicians). }\end{array}$ & $\begin{array}{l}\text { Evaluation of policy } \\
\text { instruments - are the existing } \\
\text { policy instruments working } \\
\text { satisfactory in the particular } \\
\text { policy domain. }\end{array}$ & $\begin{array}{l}\text { Change in existing or } \\
\text { implementation of policy } \\
\text { instruments. }\end{array}$ & $\begin{array}{l}\text { Change in policy } \\
\text { implementation instruments. }\end{array}$ \\
\hline $\begin{array}{l}\text { Learning from policy failure } \\
\text { - social learning (May) }\end{array}$ & $\begin{array}{l}\text { Policy elites in a specific } \\
\text { policy domain learn from } \\
\text { direct or indirect } \\
\text { experience with a specific } \\
\text { policy. }\end{array}$ & $\begin{array}{l}\text { Policy elites (officials, } \\
\text { bureaucrats, politicians). }\end{array}$ & $\begin{array}{l}\text { Understanding ideas - do the } \\
\text { existing ideas about the social } \\
\text { construction of the problem } \\
\text { conform to reality. }\end{array}$ & $\begin{array}{l}\text { Change in fundamental policy } \\
\text { aspects (rights, target groups, } \\
\text { goals). }\end{array}$ & Redefinition of policy goal \\
\hline $\begin{array}{l}\text { Learning from policy failure } \\
\text { - political learning }\end{array}$ & $\begin{array}{l}\text { Advocacy coalitions in a } \\
\text { specific policy domain } \\
\text { learn how to improve } \\
\text { strategy in order to better } \\
\text { advocate for a policy idea } \\
\text { or issue. }\end{array}$ & $\begin{array}{l}\text { Advocacy coalitions (interest } \\
\text { groups, unions, etc.). }\end{array}$ & $\begin{array}{l}\text { Construct strategies of how to } \\
\text { better advocate ideas and } \\
\text { advance policy problems. The } \\
\text { understanding of the feasibility } \\
\text { of the policy is also improved. }\end{array}$ & Improved arguments. & $\begin{array}{l}\text { Changes in advocacy coalition } \\
\text { strategy. }\end{array}$ \\
\hline $\begin{array}{l}\text { Policy-oriented learning } \\
\text { (Sabatier) }\end{array}$ & $\begin{array}{l}\text { Adjusting policy over } \\
\text { time. }\end{array}$ & Advocacy coalitions & $\begin{array}{l}\text { Adjusting ideas }- \\
\text { implementation of own policy } \\
\text { ideas and achievement of goals. }\end{array}$ & Adjusting existing policy ideas. & $\begin{array}{l}\text { (Changes in existing policy } \\
\text { ideas)* }\end{array}$ \\
\hline
\end{tabular}

Table 1 Theories of policy learning - Summary (Rose, 1991; Bennett and Howlett, 1992; May, 1992; Hall, 1993; Birkland, 2006; Baumgartner, 2013) 
In the Algorithm for continuous analysis of policy learning and policy change the catalyst of the process is an emergency - a specific incident (Incident 0 or the incident that is going to be used as the basis for comparison), that shocked the system. Next step (1.1.) is exploring the incident. This process takes place only when the Response phase of the Disaster management cycle has ended and Recovery phase is nearing its conclusion, and the Mitigation phase has begun. After exploring the incident the identification of critical failures ${ }^{2}(\mathrm{Q} 1)$, that caused the incident, must be assessed. If the problems that caused critical failures are not identified policy learning is impossible. As in step 1.1. - if the critical failures are not identified, preventing them from repeating in the future is impossible (F1).

The next critical step is acknowledging the problem (Q2). It must happen at the highest possible level of hierarchy. The problem must be acknowledged by actors who have the rights and power to make the implementation of corrective actions binding. If the problem is not acknowledged it cannot be solved - policy learning is impossible (F1).

After acknowledging the problem, the next step is to identify and propose essentially relevant solutions (1.2.). The solution proposed is essentially relevant if, when critically assessed, it has the potential to eliminate or mitigate the root cause problem or problems of the critical failure. The acknowledgement of the problem is critically important factor for the development of an essentially relevant solution, because it requires an in depth understanding of each root cause or causes of the problem. To gain this understanding, the competencies of a single institution might not suffice - consultants, academics and representatives of NGO's might need to be involved. Ensuring necessary competencies requires the authorisation of resources. If the necessary resources are not provided and no search for solution takes place, policy learning is impossible (F1).

\footnotetext{
2 "Critical failures" refers to "turning points" or "crossroads" (actions, inaction, decisions, etc.) in the chronology of the emergency that were detrimental to the following course of events.
} 

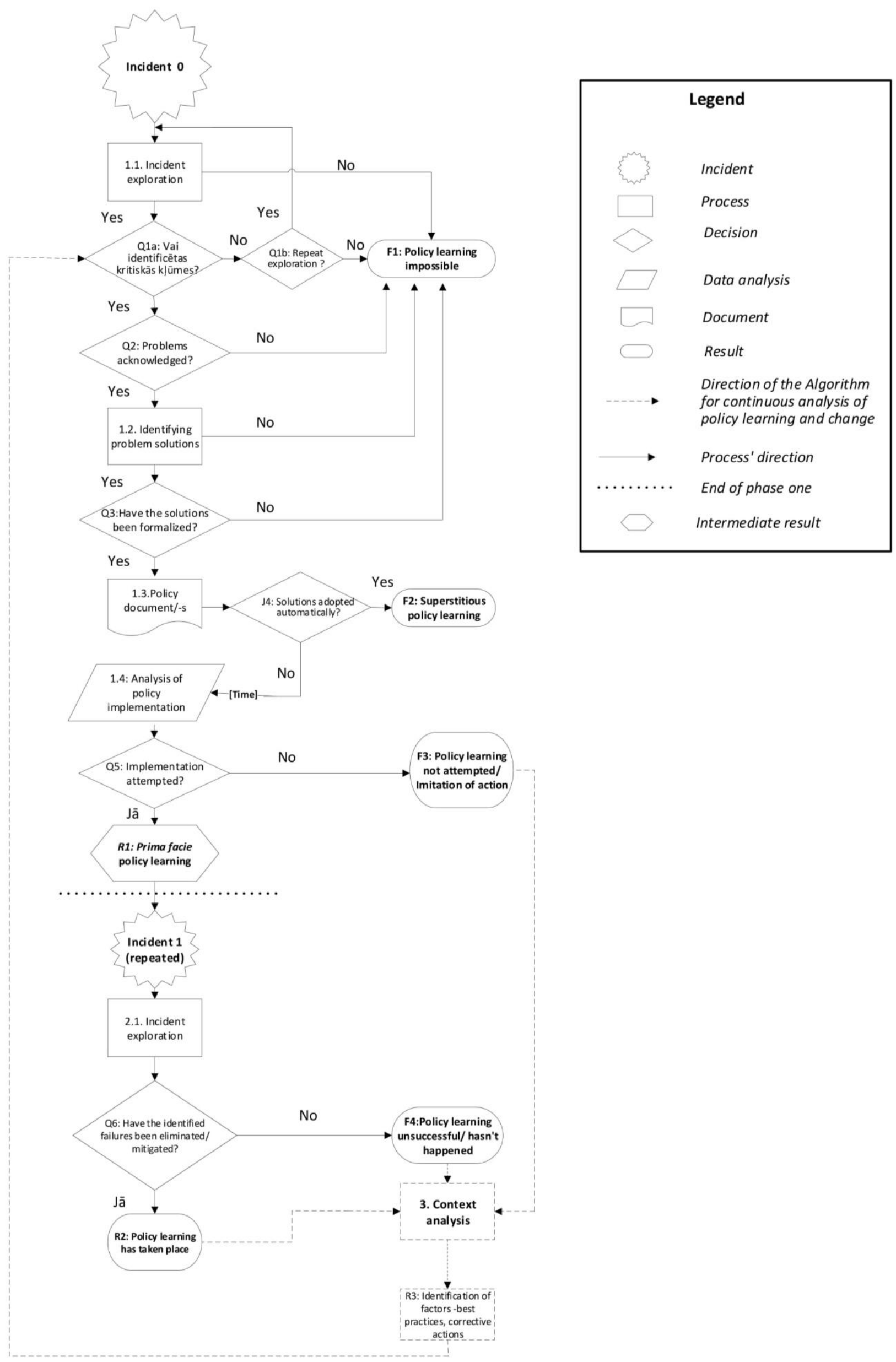

Figure 1 Algorithm for continuous analysis of policy learning and policy change 
After the potential solution for the root-cause problem have been identified, they need to be formalized in policy documents (1.3.) via policy decisions. After the formalization of proposed solution has taken place - policy decision has been made - an assessment must be made whether these solutions are based on analysis of the situation or have been adopted automatically (Q4). The automatic adoption, by replicating practices accepted and implemented elsewhere, is a strategy that can be applied when there is a lack of necessary competencies and resources or there is a need to demonstrate visible action to solve the problem. If the automatically adopted solutions show improvements in the future, it is luck and not a conscious achievement.

After policy decisions have been made, policy documents - developed and entered into force, time is needed for the solutions included in the policy documents to be implemented. The implementation deadline can be used as the first point of reference. Additionally, a mediumterm assessment can be performed to identify any problems in the implementation process and address them via corrective actions. If no deadline is set, an alternative point of reference is the ten-year time period set by Sabatier. Lastly, a yearly assessment can also be performed by producing a progress report.

Based on the assessment of numbers and facts, as well as prima facie evidence proposed by Birkland, acquired during the policy implementation, experts must give the judgement on whether policy implementation has been attempted (Q5). If the data and prima facie (policy) learning evidence suggest attempted implementation of solutions for root-cause problem or problems of critical failures, it can be concluded that prima facie policy learning has taken place (R1). Thus it is possible to anticipate that, should a similar incident take place in the future, response and recovery activities will be carried out more efficiently and effectively.

However, should the evidence not suggest successful policy learning (F4), a discussion is possible about why policy learning was not attempted; has there been imitation of action, for example, the institution's annual reports list various policy implementation activities, however 
data, numbers and evidence presented in a third party assessment or collected during research do not suggest a real progress in achieving policy goals.

The judgement about prima facie policy learning concludes the first phase of the algorithm. To judge the true effectiveness of the implemented policy solutions, practical testing is required - a repeated incident (Incident 1 ) that is as similar as possible to the original one. It must be emphasized that two identical incidents - emergencies - are not possible.

After a repeated incident has taken place (Incident 1), it should be explored (2.1.) to understand, if the failures identified during the exploration of previous the incident have recurred and if their root-cause problems have been eliminated or mitigated (Q6). If this has happened, it is possible to make a substantiated statement that policy learning has taken place (R2). If during the exploration of the incident no evidence suggests that the actions taken have eliminated or mitigated the critical failures identified during the exploration of Incident 0 , it is possible to conclude that policy learning has been unsuccessful. Additional analysis of the circumstances of Incident 1 might reveal new critical failures that had not yet been identified. For continuous policy learning to take place it is necessary to analyse the context in which the policy learning has or has not taken place (3.).

If it is concluded that policy learning was not attempted or policy learning has been unsuccessful (F4), context analysis (3.) is a tool for identifying factors that have impeded policy learning and policy change in this specific case. Based on this information, corrective actions can be developed and implemented (R3) and it is possible to attempt the first phase of the policy learning (and policy change) algorithm anew. However, in cases when the evidence suggests that policy learning has taken place, context analysis provides information about factors that have promoted policy learning, thus creating best practices that might be of use to other institutions. Now "Incident 1 " becomes "Incident 0 " and the process of continuous policy learning and policy change restarts form the step of identifying critical failures. 


\section{Methodology}

The goal of this publication is to perform an ex post evaluation to: 1) assess whether policy learning and policy change took place after the 2006/2007 influenza season in Latvia and 2) to explore why policy learning and policy change did or did not take place. As more than 10 years have passed since the incident, there has been enough time for ne policies to be developed, implemented and yield effects. To make judgements about policy learning and policy change after the 2006/2007 influenza season in Latvia in the context of this publication, three questions must be answered:

Q1: How did policy learning happen in practice compared to the theoretical model after the 2006/2007 influenza season in Latvia?

Q2: What critical failures were identified and corrected or mitigated after the 2006/2007 influenza season in Latvia?

Q3: What factors that promoted or hindered policy learning can be identified in the context of the 2006/2007 influenza season in Latvia?

This explanatory research was performed by collecting and analysing secondary data: news articles, policy documents, online publications by stakeholders, reports, etc. Initially an attempt was made to collect the data using data scraping software. However, this method yielded many redundancies - e.g., several identical articles published in different sources. This was concluded to produce distortions in the data set that would require too much time and resources to resolve, which was not deemed rational or effective from the researcher's point of view. Thus a different approach was formulated and incident analysis was performed utilizing the Empirical analysis process diagram (Figure 2).

Based on the diagram, the Algorithm for continuous analysis of policy learning and change and the Model of Event-related policy learning the following analysis units were defined: 1) individual entries/publications derived from LETA - the leading news agency in 

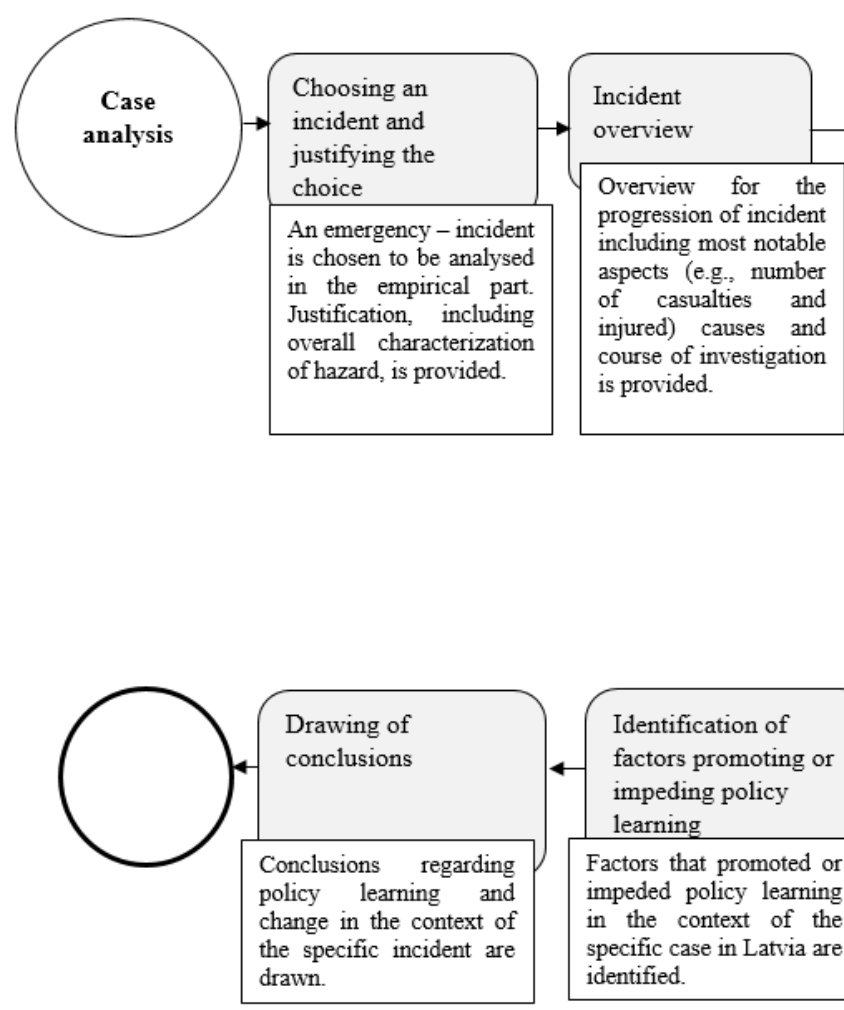

\begin{tabular}{|c|}
\hline $\begin{array}{l}\text { Definition of key } \\
\text { words and categories, } \\
\text { collection of data }\end{array}$ \\
\hline $\begin{array}{l}\text { Key words for } \\
\text { information search are } \\
\text { defined. Categories for } \\
\text { sorting data are defined. } \\
\text { Data from LETA archive } \\
\text { is collected. Data is } \\
\text { entered into MS Excel } \\
\text { spreadsheets. Each years } \\
\text { has an individual } \\
\text { spreadsheet. }\end{array}$ \\
\hline
\end{tabular}

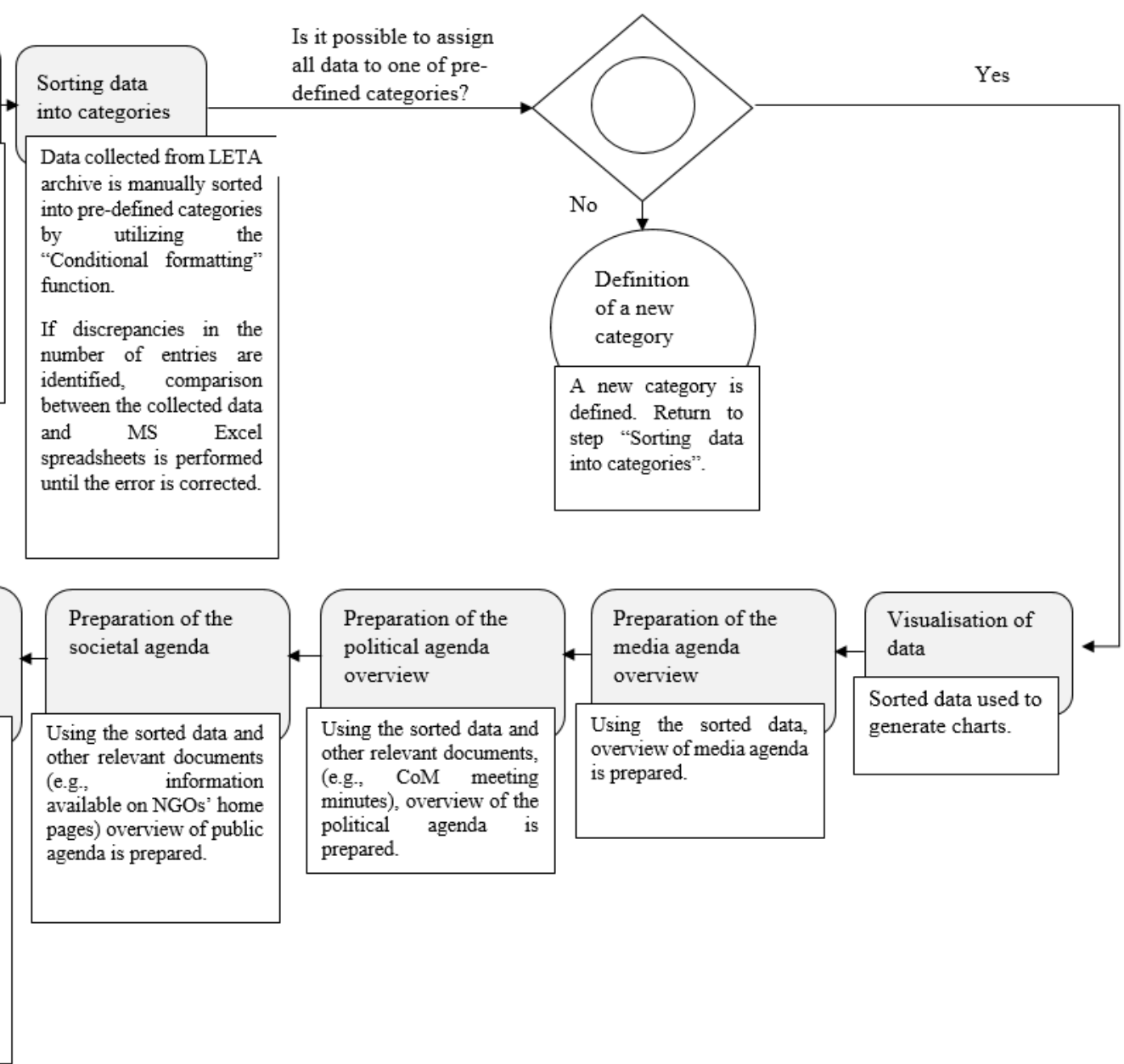

\section{Figure 2 Empirical analysis process diagram}


Latvia - archive (media agenda) and from stakeholder homepages and other news sources (public agenda); 2) The Cabinet of Ministers minutes that were derived from sites tap.mk.gov.lv and www.likumi.lv (political agenda) and 3) legal acts and policy planning documents, that were derived from sites www.likumi.lv and polsis.mk.gov.lv.

Categorization strategy was applied to the manually collected qualitative data needed to construct the overview of media agenda. The collected data was coded by applying inductively created topical data categories. If needed the topical data categories were re-defined, supplemented and the data was manually sorted anew in accordance to the new categories.

In order to limit the time frame for policy documents analysed, data search on the site www.likumi.lv was conducted by applying the Issue attention cycle model by Anthony Downs. The application of this model was deemed appropriate since public health issues have the potential to be relevant to large societal groups both domestically and globally. The model consists of five stages: 1) The Pre-problem stage; 2) Alarmed Discovery and Euphoric Enthusiasm stage; 3)Realization of costs stage; 4) Decline in intensity of interest stage; and 5) the Post-problem stage (Gupta and Jenkins-Smith, 2015). Per this model, if the issue is costly, uninteresting or not dramatic enough, and if solving it will not yield large returns or negatively impact the status quo of powerful people (Gupta and Jenkins-Smith, 2015), the issue will quickly move through the phases of the model and disappear from media, political and public agendas.

\section{6/2007 influenza season in Latvia}

The regular, yearly patterns of influenza outbreaks combined with the inherent human tendency to forget and the many issues that compete for our attention on a daily basis foster complacency and mindlessness. This was evident at the very beginning of the Covid-19 spread: as it was equated with the seasonal influenza virus, people were inclined to carry on as usual. Only when the numbers of daily cases reported started skyrocketing and more information about the infection became known, did the policymakers start taking action. A shock to the 
system is required for the three main stakeholders - the policymakers, the media and the public - to focus their attention on a specific issue, keep it on the agenda and take action.

In the 2006/2007 influenza season a record number of people infected was registered in Latvia. (SVA, 2007; Perevoščikovs, 2018) Since Latvia has a small population ${ }^{3}$, a comparatively smaller shock created by an emergency - in this case, the spread of an infectious disease - would be needed to significantly burden the functioning of various circulation systems - the capabilities of the health care system could be exceeded, there would be complications with ensuring internal and external security as well as with providing other critical goods and services. And, since there have been issues with meeting the demand of flu vaccines in the past under routine circumstances (Kinca, 2005; Ilgaža, 2010; LETA, 2016b) and the production of said vaccines is a time consuming and limited process, it is certain that in the case of a pandemic influenza outbreak vaccinating everyone or only those in high-risk groups would be impossible. Thus there are several reasons why the 2006/2007 influenza season was chosen as the incident to be explored in this publication from the perspective of policy learning and evidence based policy making: firstly, the nature of the disease itself. The influenza virus develops and mutates continuously, to ensure its survival and thus creating regular epidemic and pandemic outbreaks. Since the $16^{\text {th }}$ century 14 influenza pandemics have been documented of which the 1918 Spanish flu might have been the deadliest one yet. (Taubenberger and Morens, 2010)

Secondly, globalization fosters fast "microbial traffic". Research of globalization, tendencies of individual movement and development have shown that with the development of technologies and socioeconomic factors the mobility of every next generation has increased tenfold (Ali and Keil, 2006) thus allowing various pathogens to cross greater distances faster than ever before. (Ali and Keil, 2006; Webster, 2010; CDC, 2012) This in combination with growing urbanization makes it more difficult to contain the spread of a virus. Vulnerability is

\footnotetext{
${ }^{3}$ As per data of the Official statistics portal the population of Latvia was 1,8 million at the beginning of 2021, and 2,2 million at the beginning of 2007. (Official satistics portal, no date)
} 
also magnified by the emergence and spread of infectious diseases that are resistant to antimicrobial medications. It is said that these resistant pathogens cause roughly 23 thousand deaths in the USA and 25 thousand deaths in Europe and cost roughly 20 and 1,5 USD billion in direct or indirect losses respectively. (Gelband et al., 2015, p. 8) These resistant pathogens can only be countered by an alternative antimicrobial medication or a combination of several of these, which might not always be available. Finally, based on everything described above, infectious diseases have the potential to inhibit or even paralyze circulation of goods, services and people. (Elbe, Roemer-Mahler and Long, 2014) "A pandemic is essentially an unpredictable and dangerous system of viral circulation" (Elbe, Roemer-Mahler and Long, 2014, p. 448) that endangers all other systems of circulation. "The ultimate effect of a pandemic is also that it ends up shutting down all other systems of circulation, leading to stasis. A pandemic is the quintessential "crisis of circulation" because it is a circulatory threat to the very notion of circulation itself." (Elbe, Roemer-Mahler and Long, 2014, pp. 449-450) If we also take into account the possibility of various pathogens being weaponized and used for bioterrorism (Miro and Kaufman, 2005; Anderson and Bokor, 2012; Zapanta and Ghorab, 2014), it is undeniable that infectious diseases have transcended the public health sector and become a central element of the Global Public Health Security.

In sum the 2006/2007 influenza season can be classified as a quasi-incident: an emergency that serves as a warning by exposing the flaws and vulnerabilities of a specific domain or the system as a whole. Thus the 2006/2007 influenza season in Latvia is a valuable source of information for analysis which would allow for targeted, evidence based policy making for improving pandemic readiness.

\section{Timeline}

The 2006/2007 influenza season in Latvia did not follow the usual pattern - the first patients were identified only during the $2^{\text {nd }}$ week of 2007 (Brenčeva, 2007) which is roughly 
14 weeks later than usual. Despite expert predictions about the rate of infection increasing only in march just three days later after the admission of the first patients - February $15^{\text {th }}-$ the epidemiological threshold ${ }^{4}$ was reached in two cities. (Gleizde and Ozola, 2007) By February $20^{\text {th }}$ the epidemiological threshold was reached on the state level, growing from just 32 cases per 100000 inhabitants to 172 cases per 100000 inhabitants within a week. (Gleizde, 2007c) The infection rate continued to accelerate - the number of cases increased trifold between February $19^{\text {th }}$ and February $25^{\text {th }}$. (Tomsone, 2007) By February $27^{\text {th }}$ hospitals approached maximum capacity as infection rates exceeded the epidemiological threshold 14 times.

On March $1^{\text {st }}$ the Minister of Health tasked the State Agency of Compulsory Health Insurance to work together with representatives of emergency medical services to address the issue of additional funding in order to ensure the provision of necessary healthcare services. (Gleizde, 2007a) This resulted in extended working hours of family doctors and resident doctors being recruited to work in the Riga Emergency medicine station. (Gleizde, 2007b) This was an untraditional but necessary solution, because "during the flu epidemic about 1200 calls per day were received of which roughly 900 were responded to". (Gleizde, 2007b) The resident doctors were also involved in assisting with the care of the influenza patients at the big hospitals in Riga. (Gleizde, 2007b)

The infection rate started going down by the end of March. (Karaseva, 2007; LETA, 2007; Ozola, 2007a, 2007b; Vespere, 2007) The epidemic ended on April $4^{\text {th }}$. (Kḷanska, 2007) According to the information in the Epidemiology Bulletin "Overview of the incidence of acute upper respiratory infections (AURI) and influenza in the 2006-2007 epidemic season" released by the State Agency "Public Health Agency" “"During the 2006-2007 epidemic season the maximum registered incidence of AURI (2597.1 per 100000 population) and influenza (932.9

\footnotetext{
${ }^{4} 100$ cases per 100000 inhabitants.
} 
per 100000 population) exceeded the number of incidences recorded during the previous six seasons". In sum 216315 cases of influenza infection were registered.

\section{Analysis - agendas and critical failures}

In order to broaden the context of the seasonal influenza trends and their place in various agendas over time, data from the LETA archive was collected for the time period from 01.01.2000 until 31.12.2017 ${ }^{5}$ using the keyword "gripa" (the flu) in the "news" category, which is enabled by the cyclical nature of the disease. A total of 3056 news reports were collected of which 2729 were classified as original, meaning they were not duplicates or updated entries. These were further sorted into nine inductively defined data categories: 1) Information about influenza trends; 2) Political agenda; 3) Public agenda; 4) Irrelevant background information, e.g., news about celebrities having the flu; 5) Emergencies and capitalism - information about restrictions and opportunities for businesses and economy; 6) Unrelated information; 7) Value background - information that illustrates political and public agendas and their values regarding public health; 8) Other infectious diseases - influenza is mentioned as an example; 9) Disruptions in circulation.

\footnotetext{
${ }^{5}$ The time frame was defined by taking into account both the availability of data and Sabatier's notion that about 10 years are needed for policy change to yield results after being implemented.
} 
Figures 3 and 4 illustrate the intensity of news articles about influenza being published by LETA. During the 17 year period the only outlier is the year $2009^{6}$ when information about influenza was posted during the summer as well. This was due to the pandemic influenza H1N1 virus. It must be noted that in the news H1N1 was mostly named the "new flu".

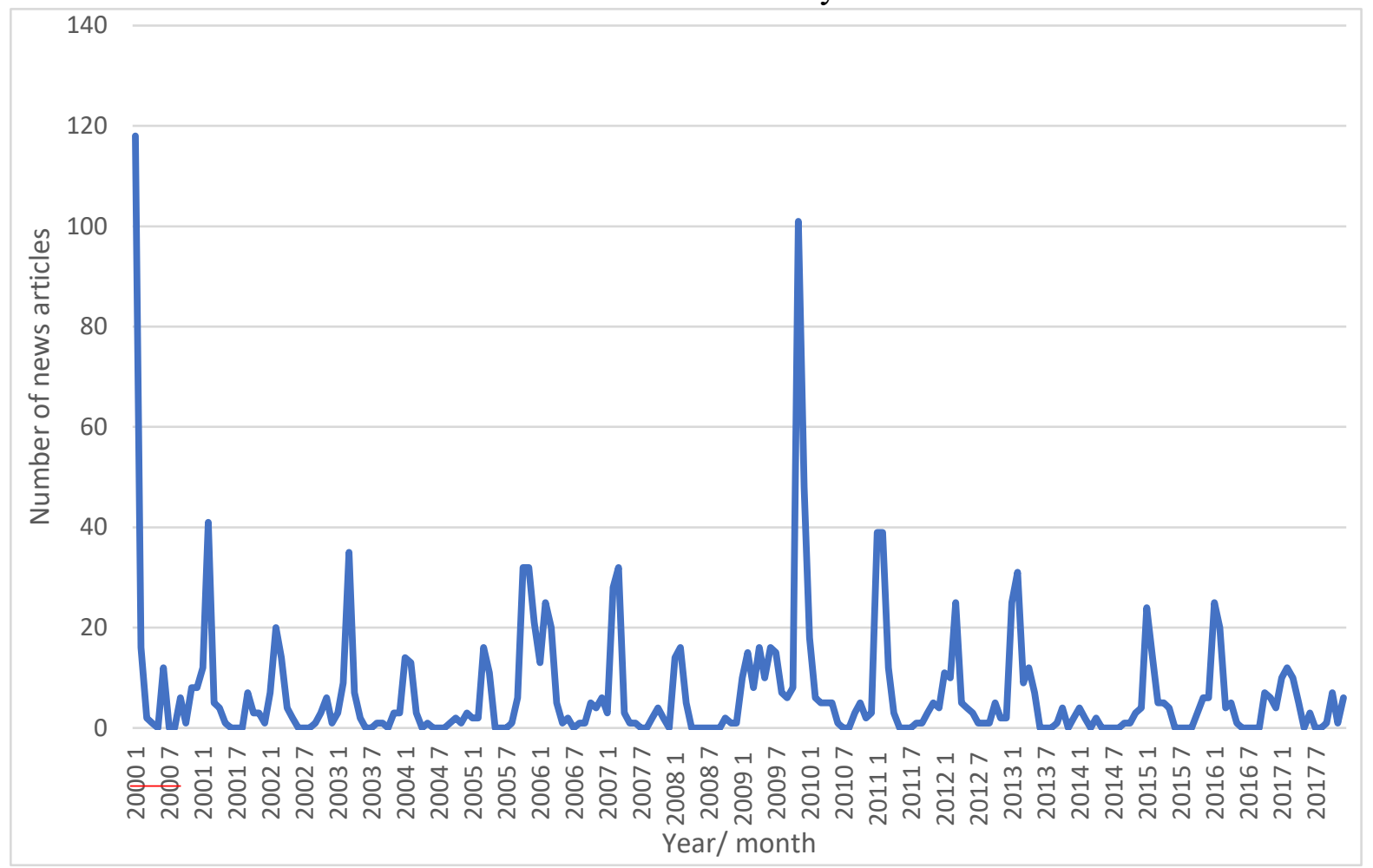

Figure 3 Problem attention cycle - influenza, 2000 - 2017

Even though this not have the same connotation as "pandemic flu" it still creates a heightened sense of threat. "New" is one of the strongest motivating words used in marketing (Cooper, 2008) and in the context of influenza it has a negative connotation, because it refers to a never before seen threat or hazard that might not be easily managed or mitigated. Thus, by using the word "new" sensationalizes the issue and the reader is motivated to click on the article which translates into more traffic and advertising revenue for the site.

From the perspective of Down's Issue attention cycle influenza has a large potential to gain a prominent spot on the media agenda: 1) it has the potential to affect a large number of people, especially those who are already more vulnerable to the disease and the complications

\footnotetext{
${ }^{6}$ The year 2001 is not classified as an outlier, because only 17 news articles refer to the 2000/2001 influenza epidemiological season as illustrated by the red line (-).
} 


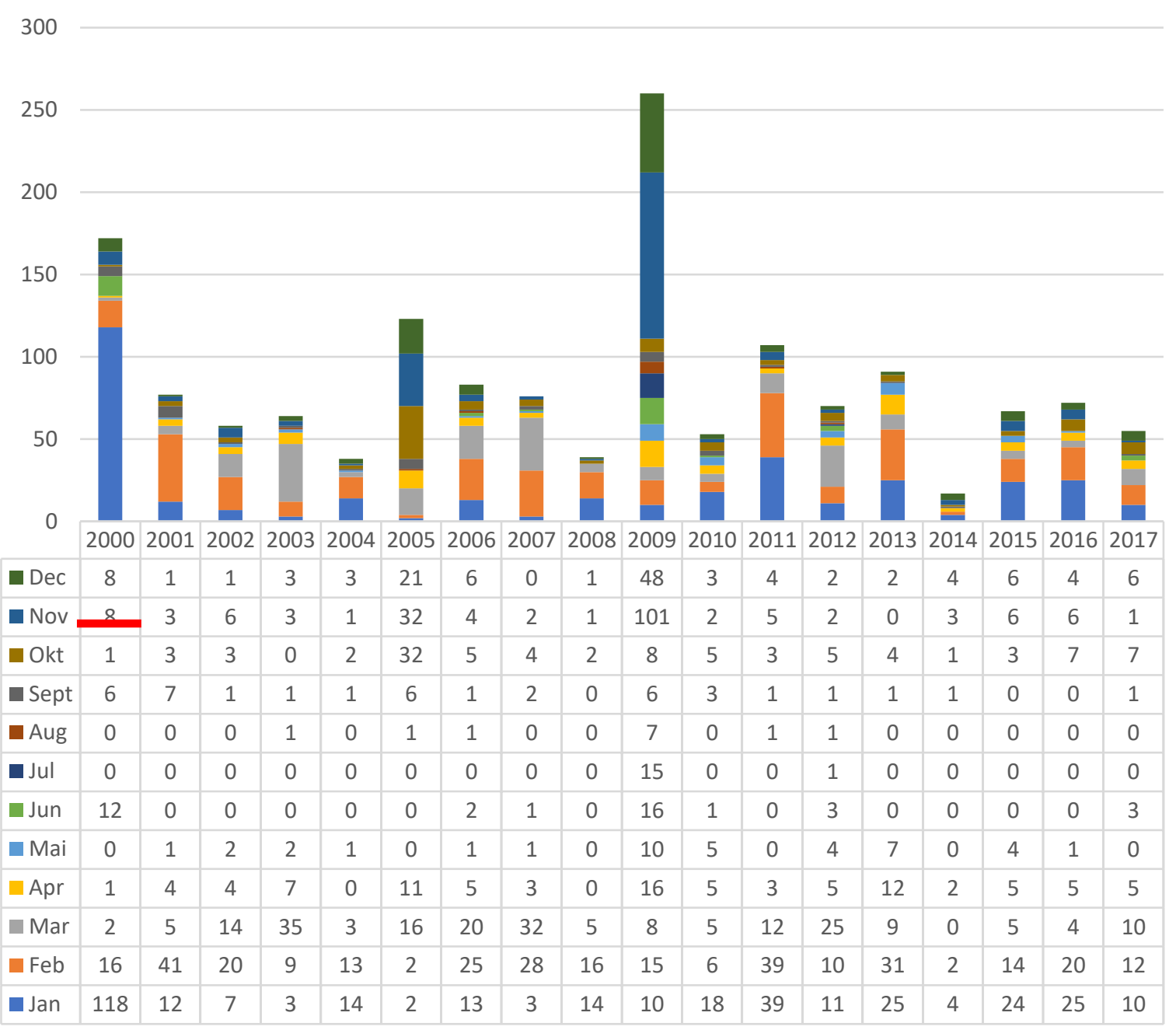

Figure 4 Media agenda - influenza

it causes due to pre-existing conditions or age; 2) it has the potential for both (high) negative financial implications ranging from the individual (e.g., paying for the flu vaccine) to businesses (e.g., revenue lost due to sick leave) and economy as a whole, as well as the potential for profiting from an emergency situation be it by developing medications or by supplying medications and equipment both legally and illegally, also known as "disaster capitalism" (Klein, 2007, p. 6); thus 3) this issue is interesting - people will likely be interested in reading the corresponding news reports. This last aspect is also fuelled by people's "morbid curiosity" or "morbid fascination" - the interest about death, disaster and other highly negative information (Scrivner, no date; Burkeman, 2012)- thus encouraging griefsplotation ${ }^{7}$.

\footnotetext{
${ }^{7}$ Griefsplotation - a situation when death, tragedy an suffering are used as, for example, a tool for motional manipulation in marketing (Mahdawi, 2017). Media implement this by publishing shocking titles without
} 
In the 17 year period explored in this publication, the media mostly reported the trends of influenza spread (category 1 - 1254 news articles), followed by news articles on influenza's place on the political agenda, e.g., commentary from politicians and announcements by various institutions. The third biggest set of articles fell into category 3 - reports on celebrity health etc. Finally, news articles that were classified in category 4 - public agenda - were the fourth biggest set, e.g., looking at various polls or reporting expert opinions. This allows for the conclusion that "influenza" does not take a prominent place in the media agenda and moves quickly through the phases of Down's Issue attention cycle - even though some attention is devoted to the topic, it's superficial and dissipates as soon as the influenza season has ended. Consequently, the issue of seasonal influenza does not have the media support to command the public and political agendas, to foster analysis and subsequent preparedness measures.

In order to ensure a better comparison, exploration of the political agenda was divided in two periods - before and after the 2006/2007 flu season. The first time influenza was mentioned in the Cabinet of ministers minutes was in $2005^{8}$ when an informative report regarding the potential action scenarios in case of a pandemic influenza outbreak were discussed. (Veselības ministrija, 2005) Other results for the time period before the 2006/2007 influenza season included confirming Latvia's official position on H1N1 (colloquially known as the "bird flu"); Latvia's official position on the human health aspects in case of a pandemic influenza outbreak; and Latvia's official position on European Union regulations regarding the bird flu. (LR Ministru kabinets, 2005b, 2005a, 2005c)

Since the amount of data obtained from the official sites for normative acts and their projects and Cabinet of ministers minutes (www.likumi.lv and tap.mk.gov.lv $\left.{ }^{9}\right)$ was minuscule,

providing relevant or new information in the article itself, in order to increase traffic and the profits derived from advertising.

${ }^{8}$ It must be noted, that a potential explanation for the low number of results obtained is the fact that the digitalised Cabinet of Ministers minutes were only made available starting 2005.

9 The search for the keyword "gripa" yielded 0 results on the official site of Latvijas Republikas Saeima (the parliament) (titania.saeima.lv). 
additionally the reports on political agenda in the media were also analysed. These news reports mostly contained various government institutions calling the public to vaccinate, expressing expert opinions as well as reporting current trends of influenza spread. The political agenda of individual municipalities was mostly published by the media in case of various restrictions, e.g., limiting public gatherings or declaring quarantine in the local hospital.

In January of 2005 media reported, that the government is preparing a readiness plan for an influenza pandemic and bioterrorism threat according to the guidelines from European Union and the World Health Organization, e.g., ensuring that $75 \%$ of the population receive the flu vaccine. (Ādamsone, 2005) The working group tasked with producing these two documents was comprised of specialists form many institutions and areas: Ministry of Health, "the Centre for infectious disease, Centre for Disaster medicine, State Agency of Medicines, Ministry of the Interior, State Fire and Rescue Services, Ministry of Agriculture and National Armed Forces". (Ādamsone, 2005) Although both documents were due to be submitted by April $15^{\text {th }}$ and May $15^{\text {th }}$ respectively, this did not happen. The plan regarding action in the case of pandemic influenza first surfaced only in August and was confirmed in October. No information about a plan or any document regarding bioterrorism threat could be found. This allows for the conclusion that the political agenda regarding both seasonal and pandemic influenza changes reactively and is largely a formality. Even when a task requiring action - developing or regularly updating a policy document - was given, there is a lack of follow-through and the issue is not given a priority status.

Finally, influenza was not a prominent topic on the public agenda either leading up to the $2006 / 2007$ influenza season. The lack of relevancy is supported, for example, by official reports about low vaccination numbers as well as frequent articles about folk remedies being an effective way to prevent and cure seasonal influenza. There were also no indications of an NGO or an advocacy group or coalition, who would actively lobby the importance of influenza preparedness and prevention. 
Based on everything mention above and on the analysis of the Ministry of Health's report "On the action in case of pandemic influenza", the following problems (potentially critical failures) contributing to the threat posed by influenza were identified:

- Insufficient amount of flu vaccines (in case of a pandemic);

- No contract of guaranteed flu vaccine deliveries;

- Low vaccination numbers;

- The vaccination of groups that ensure public order is not guaranteed;

- Insufficient reserves of antimicrobial medications for dealing with the complications of (pandemic) influenza;

- Insufficient funding for epidemiological monitoring, overtime pay for medical professionals, as well as ensuring communication and necessary logistics activities (in case of a pandemic).

\section{Lessons learned (?)}

An opportunity to test whether there have been any improvements made regarding the above identified (potential) critical failures presented itself in 2009 when the pandemic influenza virus H1N1 spread around the world. Although the initial spread of the virus in Latvia was not rapid, first discussions in media regarding the procurement of vaccines were published in July. As infection rates started to increase in October, the Immunization state council recommended procuring the new vaccines despite expert doubts about their safety. (Mežniece, 2009a, 2009d) The Ministry of Health later in October decided not to procure vaccines, based on the data about the trends and clinical course of the illness. The public did not share the same opinion, as various anti-influenza medications were sold out (Mežniece, 2009c) and a campaign "Put on a mask" was organized by a youth society "Pirmie" (Slišāne, 2009) who also handed out face masks to inhabitants of Riga. As in the 2006/2007 influenza season the burden on the public health sector was so big, that the option on recruiting 500 medical students to help 
provide medical help was considered. By mid-December the number of confirmed H1N1 deaths reached 17 (Mežniece, 2009e) thus a decision was made to allocate 14,2 thousand lats $(\sim 20,2$ thousand EUR) for the gradual procurement of additional anti-H1N1 medications for therapeutic purposes and to protect medical personnel. (Mežniece, 2009b)

\section{Securing vaccines (and other necessary medications)}

In March of 2006 the Ministry of Health negotiated with pharmaceutical companies and distributors about the guaranteed deliveries of antiviral medications, antibiotics and respiratory masks. (Mežniece, 2009b) However, even before the Ministry of Health issued a report on the negotiations, the government made a decision not to stockpile antiviral medications. Additionally in the "Immunization state program 2008-2010" and the "Immunization program 2012-2014" influenza was not defined as a priority.(LV Ministru kabinets, 2008, 2012) It must also be noted that the Immunization program 2012-2014 was still in force in March of 2019. In January of 2016 media reports were published about there not being enough state funded flu vaccines. (LETA, 2016a) The Minister of Health dismissed the public's concerns, claiming the agiotage was unfounded and that in the case of other infectious diseases a vaccine shortage would be impossible. The evidence collected suggests otherwise - there have been vaccine shortages even for diseases that are on the top priority list: a combination vaccine for diphtheria and tetanus in adults (Balčiute, 2018); against measles, rubella and mumps in children (Dzērve, 2017), and tuberculosis (Dzērve, 2012).

\section{Improving vaccination numbers}

In 2007 in an article in the publication for medical professionals "Doctus" infectologist I. Mazjanis commented on various research regarding the trends in influenza research and the preparedness of Western countries for a new influenza pandemic. He concludes that the situation in Latvia is much worse than in the USA and Norway. His claims are also supported 


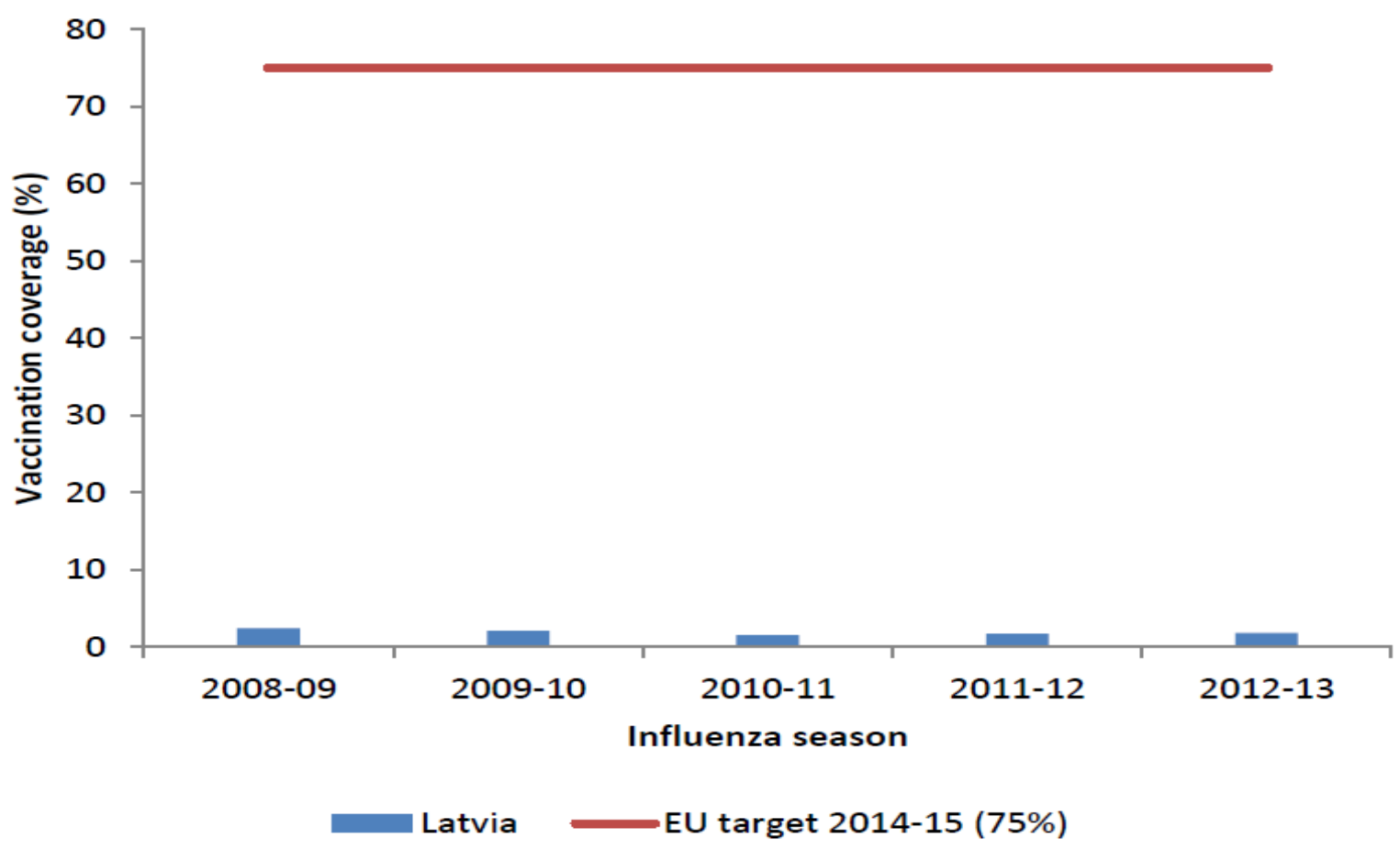

Figure 5 Seasonal influenza vaccination coverage among those $\geq 65$ years of age from the 2008-09 to the 2012-13 influenza season from (ECDC, 2013, p. 4)

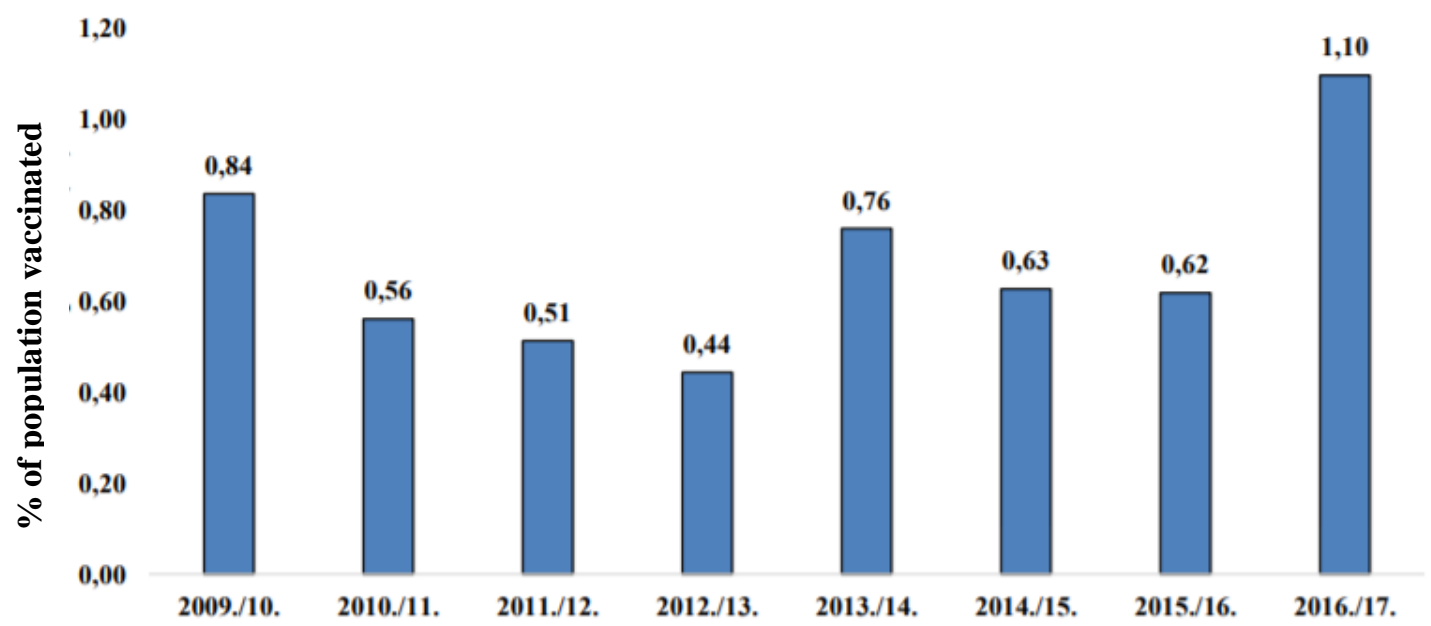

Figure 6 Level of influenza immunization in the Latvian population by influenza seasons from(Nikiforova et al., 2017, p. 16)

by the data published by the European Centre for Disease Control (ECDC) (Figure 5) and the Centre for Disease Prevention and Control (Figure 6).

Even though the number of people vaccinated has increased it is still very far away from the $75 \%$ mark for people in the high-risk groups as recommended by ECDC and WHO. This as 
well as the information presented above leads to the conclusion that provision of vaccines and implementation of immunization activities in neither on the political nor public agendas. This increases risks of infections and complications, that can overwhelm the capabilities of public health sector. It must also be noted, that other healthcare needs, e.g., in cases of chronic illnesses and accidents, that might require the same technological resources (e.g., ventilators) for treating influenza complications do not disappear during the flu season. Finally, the low levels of people vaccinated and lack of a medications stockpile or guaranteed delivery contract also endanger the many other circulation systems needed for the continuity of economic processes in the country.

\section{Funding}

Latvia has one of the lowest levels of healthcare funding in the European Union as illustrated by Figure 7.

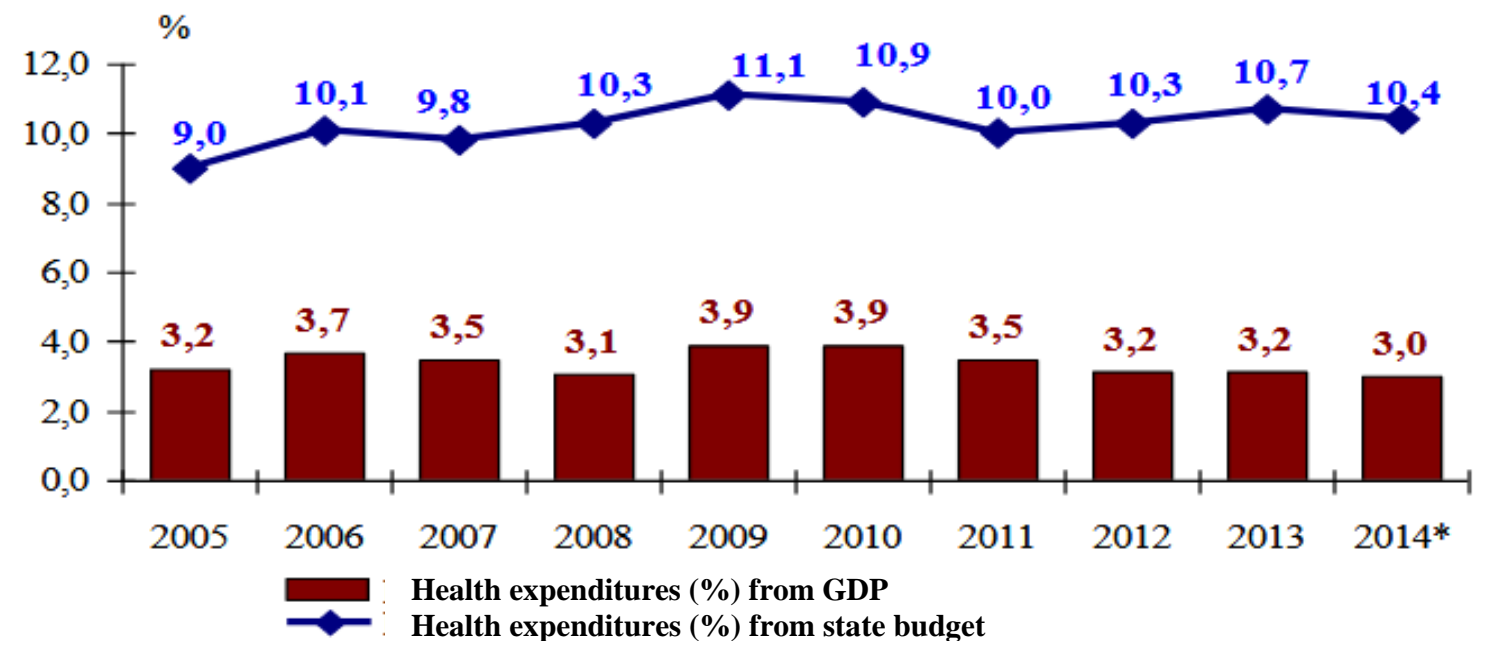

Figure 7 Expenditure on health from GDP and from the general state budget in Latvia, 20052014,\%, from (Renemanis, 2015, p. 82)

After 2014 the gap between the budget of the public health sector as a whole and the budget health care domain started to increase: between 2014 and 2017 the gap increased by $8 \%$ the as the designated funding for healthcare domain fell to $80 \%$ of the total budget of the sector.

Issues with insufficient funding became acutely apparent in the last months of 2018 as employees en masse terminated their employment with the State Emergency Medical Service 
of Latvia thus jeopardizing the continuous provision of emergency medical services in Riga region ${ }^{10}$. (Delfi, 2018) A state of emergency was declared at the beginning of November, and the Latvian Association of Emergency Medicine Specialists even turned to the European Parliament for help with resolving the issues of low pay and it being further decreased in the future as well as the low prestige of the profession. The state of emergency was terminated on January $1^{\text {st }} 2019$ due to improvements in material technical resources as well as revisions in Labour law that allowed medical professionals to work more overtime (LETA, 2018), which is in direct contradiction with the complaints of medical professionals being tired and overworked. It is also not rational to expect, that this solution will be sustainable or increase the prestige of the profession in any way.

\section{Conclusions}

By applying the Algorithm for continuous analysis of policy learning and change to the case it is possible to conclude, that there has been a partial exploration of the incident, which is represented by the monitoring performed by the Centre for infectious disease (epidemiological bulletins and yearly reports on AURI and influenza spread). However, these documents only contain statistical data without exploring what potentially fostered or impeded the specific development of events. A potential source of this information is the 2005 informative report "On action in case of pandemic influenza" where existing problems are identified and several potential scenarios for action are proposed - thus the problems were acknowledged at the time. The solutions were not adopted automatically, rather they were aimed at specific problems. In sum in the case of policy learning and policy change in Latvia after the 2006/2007 influenza season the evidence leads to the result F3: "Policy learning not attempted/ imitation of action".

Within the timeframe explored in this publication no evidence was found that the Ministry of Health has analysed the implementation of the scenario that was chosen. Thus the

\footnotetext{
${ }^{10}$ Approximately $1 / 3$ of the whole population lives in Riga region.
} 
evidence leads to the conclusion that the implementation of the solution in this case was not attempted. This is also supported by the evidence that none of the identified (potential) critical failures have been rectified or mitigated. On the contrary - evidence shows that the situation in the public health sector has worsened significantly.

In February of 2019 a new wave outrage was sparked by news that the pay increase for medical professionals, that was made into law in 2018 , will be smaller than expected. Some medical professionals even reported a decrease in wage of 100 or 200 EUR. (Krieviņš, 2018) Head of Human resources of the Pauls Stradins University hospital - one of the leading hospitals in the country - commented that: "A crisis cannot be prevented as long as we do not have enough personnel on the labour market. And as long as we do not have state level solutions on how to motivate (people) the crisis will remain!". (Kinca, 2019) The severity of the situation was also illustrated by the information on the lack of specialists which in turn results in longer waiting times for the patients. (Anstrate and Feldmanis, 2019) Report Latvia: Country Health Profile 2019, State of Health in the EU even states that "the number of practising doctors in Latvia is slightly below the EU average, at 3.2 doctors per 1000 population, the number of nurses is less than half the EU average". (OECD/European Observatory on Health Systems and Policies, 2019, p. 12) It must be noted that the first alarms regarding the shortage of healthcare professionals were rung in $2007^{11}$ in the publication "Doctus", when there was a shortage of 634 doctors and the future expected shortages by 2010 where projected from 1070 to 2740 doctors, and a shortage of around 550 emergency medical service doctors within 3 years. (Ričika, Ādamsone and Celmiņa, 2007)

Now that the first two research questions of this publication have been answered, the last one remains: What factors that promoted or hindered policy learning can be identified in this case? The data collected during the exploration of this case yielded no evidence of t external

\footnotetext{
${ }^{11}$ The publication refers to data collected by the Ministry of Health in 2005.
} 
factors that promote policy learning: the media attention to influenza fluctuated in accordance to seasonal influenza trends in the Northern hemisphere and influenza was a topic on the political agenda only when there was a need for sanctioning additional resources. There were some indications of advocacy group activity, however these were sporadic and did not command the necessary media, public or political attention. The advocacy groups - various professional organizations - are more preoccupied with other issues that have a greater impact on the daily lives of their members, e.g., remuneration and working conditions.

The evidence suggests that regarding influenza Latvia prefers what Rouse calls "trying more of the same", by investing in existing policies with the hope that these investments will help change the existing unsatisfactory status quo. As no evidence of regular analysis and adjustments were identified, this is a logical course of events. Without an understanding of the specific contexts, its problems and their root causes, evidence based policy making is impossible. Thus the path of least resistance and effort is chosen.

Regarding factors that hinder policy learning the evidence suggests that there is grounds for discussing an unwillingness to take responsibility, rhetoric barriers to learning and ignoring and denying warnings. Unwillingness to take responsibility is illustrated by the decision that Latvia will not stockpile medications or sign contracts of guaranteed medications deliveries, which would require regular investments. Rhetoric barrier to learning, which is created by reliance of past success, and denying or ignoring warnings is illustrated by the unwillingness to mitigate or resolve the identified (potential) critical failures, and by only giving an apparent importance to influenza.

Lastly, one more factor that hindered policy learning and change in this case must be mentioned - the quality of available information. For example, no data regarding the high-risk group, except for people over the age of 65 , vaccination trends and information about their motivation is collected. Thus a complete understanding of the objective reality in the country 
cannot be gained. Additional vulnerability is posed by the fact that policy documents do not get reviewed and updated on a regular basis. For example, the Ministry of Health's informative report "On action in case of pandemic influenza" ant the Cabinet of Ministers ordinance Nr. 709 with the same name (still in power in 2020) does not reflect the objective reality of the public health sector. For example, the report states that there are 84 hospitals that could be re-profiled in case of a pandemic. (LV Veselības ministrija, 2005) However the 2015 Influenza readiness plan does not contain this kind of information. According to the information available on the Ministry of Health home page, in 2012 there was only 21 hospitals that provided 24/7 medical help. As per the information provided by the National Health Service, the number remained the same in 2017, however of these 21 hospitals only 11 took part in the 2017/2018 influenza season monitoring.

\section{Discussion}

The conclusions drawn based on the evidence collected during this research proposes an interesting and grand question for future research - is public health truly a priority in Latvia or is it just "on paper"? Even though the conclusions drawn during the analysis of this incident cannot be generalized, they provide valuable insights and evidence that could be used to argue for the latter. To make a more generalizable judgement a wide array of research spanning three decades would be required, e.g., by comparing the goals and indicators defined in the government declarations and their de facto implementation. A valuable source of information would also be the public's self-assessment regarding their health and well-being, their experiences with receiving various healthcare services - ease of access, affordability, availability of information, etc.

From the perspective of economy, the public health sector is investment-heavy and its contributions are subtler and more subjective to the individual. Issues regarding public health are incredibly complex and them being resolved is often dependant on other sectors doing well. The stigma surrounding various illnesses - e.g., mental health issues, HIV, AIDS - also 
contributes to the difficulty of them being prioritized de facto and "not just on paper". However, sacrificing Public health sector's interests and capacity building on a regular basis only contributes to the existing problems growing bigger, more complex and more expensive to fix as time passes until the system eventually reaches the point of no return.

Another topic for future research is the currently ongoing Covid-19 pandemic and its management in Latvia, as it might prove to be the shock necessary for policymakers to finally start actively looking for and implementing solutions for the issues and critical failures identified in this publication as well as revealed by the Covid-19 pandemic itself. It will also allow for the analysis of such dimensions as managing communication with the public, dissemination of information, intra- and intergovernmental cooperation, combating misinformation etc. These topics will not lend themselves to immediate comprehensive research and judgment as policies take time to be formulated and implemented and the events are still unfolding. However, as mentioned before, regular monitoring, even after comparatively short amount of time has passed, is a valuable source of information regarding the current progress and issues that need to be corrected. Even before the Covid-19 pandemic, there was an abundance of issues in the public health sector in Latvia, some of which are illustrated by this publication, that need to be remedied via new, evidence based policies. If no action is taken, one can argue that Latvia eventually will encounter a public health emergency it won't be able to manage and require outside help and resources to ensure the continuous functioning of various circulation systems as well as ensuring the protection of the external border of the European Union. 


\section{Bibliography}

Ādamsone, A. (2005) 'Izstrādās gatavības plānus gripas pandēmijai un bioterorismam', LETA, 23 January. Available at: http://www.leta.lv/archive/search/?patern=gripa\&item=446D3F95-89A3-4249-AA1FFEBA0E791DFC\&date=946677600,1514671200\&mode=stem,\&_fs=LETA\%0A.

Ali, S. H. and Keil, R. (2006) 'Global cities and the spread of infectious disease: The case of severe acute respiratory syndrome (SARS) in Toronto, Canada', Urban Studies, 43(3), pp. 491-509. doi: 10.1080/00420980500452458.

Anderson, P. D. and Bokor, G. (2012) 'Bioterrorism: Pathogens as Weapons', Journal of Pharmacy Practice, 25(5), pp. 521-529. doi: 10.1177/0897190012456366.

Anstrate, V. and Feldmanis, K. (2019) Slimnīcu vadìtāji ceḷ trauksmi par darbaroku trūkumu ārstniecības iestādēs, www.lsm.lv. Available at: https://www.lsm.lv/raksts/zinas/latvija/slimnicu-vaditaji-cel-trauksmi-par-darbarokutrukumu-arstniecibas-iestades.a311822/ (Accessed: 12 March 2019).

Balčiute, S. (2018) Latvijā trūkst difterijas vakcīnu pieaugušajiem; SPRK iesaka pagaidām atlikt revakcināciju, skaties.lv. Available at: https://skaties.lv/zinas/latvija/sabiedriba/latvija-trukst-difterijas-vakcinupieaugusajiem-sprk-iesaka-pagaidam-atlikt-revakcinaciju/ (Accessed: 13 March 2019).

Baumgartner, F. R. (2013) 'Ideas and policy change', Governance, 26(2), pp. 239-258. doi: 10.1111/gove.12007.

Bennett, C. J. and Howlett, M. (1992) 'The Lessons of Learning : Reconciling Theories of Policy Learning and Policy Change', Policy Sciences, 25(3), pp. 275-294. Available at: http://www.jstor.org/stable/453226. 
Birkland, T. A. (2006) Lessons of disaster: Policy Change After Catastrophic Events. Washington D.C.: Georgetown University Press.

Brenčeva, V. (2007) 'Konstatēti pirmie gripas saslimšanas gadījumi', LETA, 10 January. Available at: https://intranet.mod.gov.lv/sslvpn/PT/http://www.leta.lv/archive/search/?patern=Konst atēti pirmie gripas saslimšanas gadījumi\&item=E159520C-D073-4CC0-98EACEF6F600177F\&date $=1167602400,1168984800 \&$ mode $=$ stem,.

Burkeman, O. (2012) This column will change your life: morbid curiosity, The Guradian. Available at: https://www.theguardian.com/lifeandstyle/2012/jul/27/morbid-curiositychange-life-burkeman (Accessed: 22 June 2021).

Busenberg, G. J. (2001) 'Learning in Organizations and Public Policy', Journal of Public Policy, 21(2), pp. 173-189. Available at: http://www.jstor.org/stable/4007775.

Carley, K. M. and Harrald, J. R. (2001) 'Organizational learning under fire: Theory and practice', in Boin, A. (ed.) Crisis management Vol.III. London: Sage Publications, pp. $105-125$.

CDC (2012) 'Crisis Emergency Risk Communication'. Atlanta, GA: Centers for Disease Control and Prevention, pp. i-440. Available at: https://emergency.cdc.gov/cerc/resources/pdf/cerc_2012edition.pdf.

Cerna, L. (2013) The Nature of Policy Change and Implementation: A Review of Different Theoretical Approaches. Available at: https://www.oecd.org/education/ceri/The Nature of Policy Change and Implementation.pdf (Accessed: 22 June 2021).

Cooper, D. (2008) Power Words for Sales and Marketing. Available at: http://www.doncooper.com/downloads/Power Words for Sales and Marketing.pdf (Accessed: 7 February 2019). 
Dammann, O. (2019) 'Data, Information, Evidence, and Knowledge: A Proposal for Health Informatics and Data Science', Online Journal of Public Health Informatics, 10(3). doi: 10.5210/ojphi.v10i3.9631.

Delfi (2018) Ārkārtas situācija NMPD R̄̄gas regionālajā centrā turpinās, www.DELFI.lv. Available at: https://www.delfi.lv/news/national/politics/arkartas-situacija-nmpd-rigasregionalaja-centra-turpinas.d?id=50593403 (Accessed: 7 March 2019).

Dzērve, L. (2012) Trūkst vakcīnu pret tuberkulozi, www.diena.lv. Available at: https://www.diena.lv/raksts/latvija/zinas/trukst-vakcinu-pret-tuberkulozi-13927414 (Accessed: 13 March 2019).

Dzērve, L. (2017) Kavētās vakcīnu piegādes dēḷ ne visiem izdodas bērnu vakcinēt pret masalām, www.lsm.lv. Available at: https://www.lsm.lv/raksts/zinas/latvija/kavetasvakcinu-piegades-del-ne-visiem-izdodas-bernu-vakcinet-pret-masalam.a256039/ (Accessed: 13 March 2019).

ECDC (2013) 'Seasonal influenza vaccination Latvia 2012-13', 24(20), pp. 1-7. Available at: http://ecdc.europa.eu/en/publications/Report Assets/seasonal-vaccination-coverage-ineurope-2012-13/Seasonal-Influenza-Vaccination-Programme-Country-ProfileGreece.pdf.

Elbe, S., Roemer-Mahler, A. and Long, C. (2014) 'Securing circulation pharmaceutically: Antiviral stockpiling and pandemic preparedness in the European Union', Security Dialogue. doi: 10.1177/0967010614530072.

Etheredge, L. S. (1985) Can governments learn? American foreign policy and Central American revolutions. 1st edn. Great Britain: Pergamon Press.

Faulkner, B. (2001) 'Towards a framework for tourism disaster management', Tourism Management, 22(2), pp. 135-147. doi: 10.1016/S0261-5177(00)00048-0. 
Gelband, H. et al. (2015) The state of the World's antibiotics 2015. Washington D.C. Available at: https://cddep.org/sites/default/files/swa_2015_final.pdf (Accessed: 6 April 2017)

Gleizde, G. (2007a) ‘Gripas epidēmijas dēḷ Rīgā , Jelgavā, Daugavpilī un Rēzeknē pagarina dežūrārstu darba laiku', LETA, 1 March. Available at: http://www.leta.lv/archive/search/?patern=gripa\&item=11F65935-BC6B-4A32A1D4-9B3035DD87F0\&date=946677600,1514671200\&mode=stem,\&_fs=LETA.

Gleizde, G. (2007b) ‘Gripas epidēmijas laikā ārsti rezidenti devušies 333 izsaukumos’, LETA, 30 March. Available at: http://www.leta.lv/archive/search/?patern=gripa\&item=72D53253-4E0D-4B4E-A400BE5CE41DDC6B\&date=946677600,1514671200\&mode=stem,\&_fs=LETA.

Gleizde, G. (2007c) 'Latvijā sākusies gripas epidēmija', LETA, 20 February. Available at: http://www.leta.lv/archive/search/?patern=gripa\&item=5D93B783-0C0D-4C44BEF3-BBDDC1E99699\&date=946677600,1514671200\&mode=stem,\&_fs=LETA.

Gleizde, G. and Ozola, A. (2007) 'Rēzeknē un Jelgavā sākusies gripas epidēmija', LETA, 15 February. Available at: http://www.leta.lv/archive/search/?patern=gripa\&item=5B9DCD4B-0D45-4553B0E9-EB570AC64C97\&date=946677600,1514671200\&mode=stem,\&_fs=LETA.

Gupta, K. and Jenkins-Smith, H. (2015) 'Anthony Downs, “Up and Down with Ecology: The 'Issue-Attention' Cycle”", The Oxford Handbook of Classics in Public Policy and Administration. doi: 10.1093/oxfordhb/9780199646135.013.34.

Hall, P. A. (1993) 'Policy Paradigms, Social Learning, and the State: The Case of Economic Policymaking in Britain', Comparative Politics, 25(3), pp. 275-296. Available at: http://www.jstor.org/stable/422246. 
Heclo, H. (1974) Modern Social politics in Britain and Sweden. London: Yale University Press.

Ilgaža, M. (2010) Jaungulbenē vakcīnas jau beigušās, www.dzirkstele.lv. Available at: https://www.dzirkstele.lv/vietejas-zinas/jaungulbene-vakcinas-jau-beigusas-19154 (Accessed: 19 January 2019).

Kapucu, N. and van Wart, M. (2006) 'The Evolving Role of the Public Sector in Managing Catastrophic Disasters: Lessons Learned', Administration \& Society, 38(3), pp. 279308. doi: $10.1177 / 0095399706289718$.

Karaseva, A. (2007) ‘Austrumvidzemē gripas epidēmija beigusies’, LETA, 28 March. Available at: http://www.leta.lv/archive/search/?patern=gripa\&item=A6B915BC6B13-43D0-8694F903341C185D\&date=946677600,1514671200\&mode=stem,\&_fs=LETA.

Kinca, A. (2005) Gripas vakcīnu vienkārši vairs nav!, www.tvnet.lv. Available at: https://www.tvnet.lv/6146991/gripas-vakcinu-vienkarsi-vairs-nav (Accessed: 19 January 2019).

Kinca, A. (2019) Mediķi sašutuši - algas pieauguma vietā sarukušas; pārrēḳinu sola martā, www.lsm.lv. Available at: https://www.lsm.lv/raksts/zinas/latvija/mediki-sasutusi-algas-pieauguma-vieta-sarukusas-parrekinu-sola-marta.a309194/ (Accessed: 12 March 2019).

Kḷanska, D. (2007) 'Gripas epidēmija Latvijā beigusies , tomēr atsevišķi saslimšanas gadījumi turpinās', LETA, 4 April. Available at: http://www.leta.lv/archive/search/?patern=gripa\&item=8AA132E8-5A78-4D78A6C4-C0BF0B81BF47\&date $=946677600,1514671200 \&$ mode $=$ stem,\&_fs=LETA.

Klein, N. (2007) The Shock Doctrine: The Rise of Disaster Capitalism. New York: 
Metropolitan Books.

Krieviņš, R. (2018) Slimnīcu biedrība draud izsludināt ārkārtas situāciju slimnīcu sektorā, $w w w . l s m . l v$. Available at: https://www.lsm.lv/raksts/zinas/latvija/slimnicu-biedribadraud-izsludinat-arkartas-situaciju-slimnicu-sektora.a300643/ (Accessed: 12 March 2019).

LETA (2007) 'Ludzā, Rēzeknē , Preiḷos samazinās saslimstība ar gripu’, LETA, 20 March. Available at: http://www.leta.lv/archive/search/?patern=gripa\&item=84E0859B7DDD-4A22-A06A8EA2D783EC9A\&date=946677600,1514671200\&mode=stem,\&_fs=LETA.

LETA (2016a) 'Īsi pirms prognozētās gripas epidēmijas beigušās valsts apmaksātās vakcīnas', LETA, 3 January. Available at: http://www.leta.lv/archive/search/?patern=gripa\&item=652FC5C9-DC7E-4D94$873 \mathrm{E}-$

5B8D7D96ABCF\&date $=946677600,1514671200 \&$ mode $=$ stem,\&_fs=LETA\%0A.

LETA (2016b) Vakcinācijas kabinetos beigušās vakcīnas pret gripu, www.delfi.lv. Available at: https://www.delfi.lv/news/national/politics/vakcinacijas-kabinetos-beigusasvakcinas-pret-gripu.d?id=46979323 (Accessed: 19 January 2019).

LETA (2018) NMPD: dienesta darbinieku 'masveida aizplūšana' patlaban ir apturēta, www.DELFI.lv. Available at: https://www.delfi.lv/news/national/politics/nmpddienesta-darbinieku-masveida-aizplusana-patlaban-ir-aptureta.d?id=50752595 (Accessed: 7 March 2019).

LR Ministru kabinets (2005a) Latvijas Republikas Ministru kabineta sēdes protokols $\mid \mathrm{Nr} 72$, www.likumi.lv. Available at: https://likumi.lv//ta/id/216477?\&search=on (Accessed: 17 February 2019). 
LR Ministru kabinets (2005b) Latvijas Republikas Ministru kabineta sēdes protokols Nr. 63, www.likumi.lv. Available at: https://likumi.lv//ta/id/216486?\&search=on (Accessed: 17 February 2019).

LR Ministru kabinets (2005c) Latvijas Republikas Ministru kabineta sēdes protokols Nr. 75, www.likumi.lv. Available at: https://likumi.lv//ta/id/216474?\&search=on (Accessed: 17 February 2019).

LV Ministru kabinets (2008) Par Imunizācijas valsts programmu 2008.-2010.gadam, $w w w, l i k u m i, l v$. Available at: https://likumi.lv/ta/id/170211-par-imunizacijas-valstsprogrammu-2008--2010-gadam (Accessed: 5 March 2019).

LV Ministru kabinets (2012) Par Imunizācijas plānu 2012.-2014.gadam, www.likumi.lv. Available at: https://likumi.lv/doc.php?id=248094 (Accessed: 5 March 2019).

LV Veselības ministrija (2005) Par rīcību gripas pandēmijas gadījumā. Riga. Available at: http://www.vm.gov.lv/images/userfiles/phoebe/tas_tev_jazina_tas_tev_jazina_195448 bbbf7b0975c2257313001f19e0/riciba_gripa_pand_gadij.pdf (Accessed: 14 March 2019).

Mahdawi, A. (2017) Griefsploitation: an advertising trend that needs to die | Arwa Mahdawi | Opinion | The Guardian, The Guardian. Available at: https://www.theguardian.com/global/2017/may/21/griefsploitation-a-trend-that-needsto-die (Accessed: 19 February 2020).

May, P. J. (1992) 'Policy Learning and Failure', Journal of Public Policy, 12(4), pp. 331-354. Available at: http://www.jstor.org/stable/4007550.

Mežniece, I. (2009a) 'Imunizācijas padome: Vakcīnas pret jauno gripu Latvijai jāiepērk', LETA, 9 November. Available at: http://www.leta.lv/archive/search/?patern=gripa\&item=2063566B-4F0B-451E-BC59- 
F219C6F4FD8B\&date=946677600,1514671200\&mode=stem,\&_fs=LETA.

Mežniece, I. (2009b) 'LIC par 14270 latiem iepirks medikamentu pandēmiskās gripas ārstēšanai', LETA, 12 December. Available at: http://www.leta.lv/archive/search/?patern=gripa\&item=21E60AD5-2CCA-45B5B66D-0CF37587D094\&date=946677600,1514671200\&mode=stem,\&_fs=LETA.

Mežniece, I. (2009c) 'Lieltirgotavām beidzas pretgripas zāles ; Veselības ministrija mierina , ka zāles būšot', LETA, 10 November. Available at: http://www.leta.lv/archive/search/?patern=gripa\&item=60AFCCCD-DE07-4760A266-9E4A4F23FCCC\&date=946677600,1514671200\&mode=stem,\&_fs=LETA.

Mežniece, I. (2009d) 'Mediḳe: Vakcinēties pret jauno gripu pagaidām varētu būt riskanti', LETA, 1 November. Available at: http://www.leta.lv/archive/search/?patern=gripa\&item=BA48D36B-EBF1-446FB372-B386010923EE\&date=946677600,1514671200\&mode=stem,\&_fs=LETA.

Mežniece, I. (2009e) 'Pēc jaunās gripas komplikācijām Latvijā miruši jau 17 cilvēki’, LETA.

Miro, S. and Kaufman, S. G. (2005) 'Anthrax in New Jersey: a health education experience in bioterrorism response and preparedness', Health Promotion Practice, 6(4), pp. 430436. doi: $10.1177 / 1524839904263673$.

Nikiforova, R. et al. (2017) Pārskats par saslimstību ar akūtām augšējo elpceḷu infekcijām (AAEI) un gripu 2016.-2017. gada epidēmiskajā sezon. Rīga. Available at: https://www.spkc.gov.lv/upload/Datu bazes/gripa_2016_2017_sezona_1.pdf (Accessed: 3 March 2019).

OECD/European Observatory on Health Systems and Policies (2019) Latvia: Country Health Profile 2019, State of Health in the EU. Paris/Brussels. Available at: https://ec.europa.eu/health/sites/health/files/state/docs/2019_chp_lv_english.pdf. 
Official satistics portal (no date) IRSO10c. Population and main data of vital statistics by quarter by Indicator and Time period, Official statistics portal. Available at: https://data.stat.gov.lv/pxweb/en/OSP_PUB/START_POP_IR_IRS/IRS010c/.

Ozola, A. (2007a) 'Jelgavā aptuveni divas reizes samazinājies ar gripu saslimušo skaits', LETA, 13 March. Available at: http://www.leta.lv/archive/search/?patern=gripa\&item=83F0EF15-5BA8-429F-A07F0C855CB8AAD2\&date $=946677600,1514671200 \&$ mode $=$ stem,$\& \_f s=$ LETA.

Ozola, A. (2007b) 'Jelgavā beigusies gripas epidēmija', LETA, 27 March. Available at: http://www.leta.lv/archive/search/?patern=gripa\&item=362E1274-5140-4695-90D70BB34E247C73\&date $=946677600,1514671200 \&$ mode $=$ stem,$\& \_$fs $=$LETA.

Perevoščikovs, J. (2018) 'Vakcinācija pret gripu Fakti par gripu'. Rīga: Slimību profilakes un kontroles centrs, p. 18. Available at: https://www.spkc.gov.lv/upload/Prezentacijas/preses_konference_2.pdf.

Project Management Institute (2008) A guide to the Project Management Body of Knowledge (PMBOK Guide). 4th edn. Atlanta: PMI Book Service Center. doi: 10.1192/bjp.111.479.1009-a.

Ričika, D., Ādamsone, A. and Celmiņa, M. (2007) Mediķu trūks arvien vairāk. Ko darīt?, Doctus. Available at: https://www.doctus.lv/2007/12/mediku-truks-arvien-vairak-kodarit (Accessed: 12 March 2019).

Rose, R. (1991) 'What Is Lesson-Drawing ?', Journal of Public Policy, 11(1), pp. 3-30. Available at: http://www.jstor.org/stable/4007336.

Sabatier, P. A. and Jenkins-Smith, H. C. (eds) (1993) Policy Change and Learning: An Advocacy Coalition Approach. Boulder, Colorado: Westview Press.

Scrivner, C. (no date) The Psychology of Morbid Curiosity . Available at: 
https://coltanscrivner.com/project/morbid-curiosity/ (Accessed: 22 June 2021).

Slišāne, K. (2009) 'Jaunieši dalīs sejas maskas aizsardzībai pret jauno gripu', 20 November. Available at: http://www.leta.lv/archive/search/?patern=gripa\&item=FFEC6A9FB8E6-4528-A67476C241F46762\&date $=946677600,1514671200 \&$ mode $=$ stem,$\& \_f s=L E T A$.

SVA (2007) Pārskats par saslimstību ar akūtām augšējo elpceḷu infekcijām (AAEI) un gripu 2006. - 2007. gada epidēmiskajā sezonā. Rīga. Available at: https://www.spkc.gov.lv/upload/Infekcijas_lim_statistika/Gripas biḷeteni/Sezonas/aaei_2006_2007_sezona.pdf (Accessed: 20 January 2019).

Taubenberger, J. K. and Morens, D. M. (2010) 'Influenza: the once and future pandemic.', Public health reports (Washington, D.C. : 1974), 125 Suppl(April 2010), pp. 16-26. Available at: url: http://www.jstor.org/stable/41435296.

Tomsone, D. (2007) ‘Patlaban jau par 34 \% vairāk gripas slimnieku nekā pērn’, LETA, 28 February. Available at: http://www.leta.lv/archive/search/?patern=gripa\&item=054CB2AA-A575-439BA092-F22994A81DEB\&date=946677600,1514671200\&mode=stem,\&_fs=LETA.

Veselības ministrija (2005) Par rīcību gripas pandēmijas gadījumāa. Rīga. Available at: http://www.vm.gov.lv/images/userfiles/phoebe/tas_tev_jazina_tas_tev_jazina_195448 bbbf7b0975c2257313001f19e0/riciba_gripa_pand_gadij.pdf (Accessed: 17 February 2019).

Vespere, K. (2007) 'Latvijā samazinājusies gripas aktivitāte', LETA, 21 March. Available at: http://www.leta.lv/archive/search/?patern=gripa\&item=5FE3CC0F-329B-4B3B90D6-689DE83E7113\&date=946677600,1514671200\& mode=stem,\&_fs=LETA.

Webster, C. H. (2010) 'Airline operating realities and the global spread of infectious 
diseases.', Asia-Pacific journal of public health / Asia-Pacific Academic Consortium for Public Health, 22(3 Suppl), pp. 137S-143S. doi: 10.1177/1010539510373130.

Zapanta, P. E. and Ghorab, S. (2014) 'Age of Bioterrorism: Are You Prepared? Review of Bioweapons and Their Clinical Presentation for Otolaryngologists.', Otolaryngology-head and neck surgery: official journal of American Academy of, 151(2), pp. 208-214. doi: $10.1177 / 0194599814531907$. 